\title{
Outlook for Farm Income in 1977
}

\author{
CLIFTON B. LUTTRELL
}

$\mathbf{N}$

ET income of U.S. farmers in 1977 is expected to total about $\$ 24$ billion, approximately the same as in 1976 and 1975 according to information presented at the National Agricultural Outlook Conference in November. While realized gross farm income is expected to total more than the $\$ 104$ billion estimated for last year, production expenses are also trending upward and will probably match the increase in gross income.

Supplies of most crops are larger this year than a year ago, and barring unexpected weather develop ments, large crops will likely be harvested this fall. Record crops of com and wheat in 1976 will result in some increase in carryover stocks of grains at the close of the current marketing year as compared to the relatively low levels of last year. However, a sharp reduction in the soybean crop, down 18 percent from 1975, and somewhat smaller crops of rice and tobacco will partially offset these gains.

The volume of livestock products this year is expected to equal or exceed that of last year. Meat animal slaughter this year is expected to at least equal that of last year, being somewhat larger in the first half of the year and somewhat less in the last half. The proportions of beet and pork in the total slanghter, however, will be different, with the quantity of beef declining two or three percent and offsetting increases in pork. Poultry output is also expected to equal the rate of a year ago. Similar to the pattern of meat animal production poultry output is expected to be sharply higher in the first half of the year than a year ago, but to drop back near mid-year.

Demand for farm products is expected to continue to increase in 1977, but with the larger supplies in prospect, little change in average prices from 1976 levels is likely for either livestock or crops. Domestic demand for farm products will continue upward with

\footnotetext{
National Agricultural Outlook Conference, Washington, D.C,
} November 1976 the rising domestic incomes and population growth. Export demand has increased sharply in recent years reflecting a high rate of real income growth in many countries and the attractive relative cost of U.S. farm products. With the larger crops in some major importing nations, expont demand is expected to level off.

The average price for all fam products declined in the last half of 1976 as a result of the large crops and rising livestock production. Average prices are expected to remain near their late 1976 levels until spring or early summer when the production of livestock products may decline somewhat, causing an increase in prices.

Retail prices of food in grocery stores have been quite stable for more than a year and are expected to rise only moderately through 1977. These prices averaged about 3 percent higher in 1976 than a year earlier and another nise of about 3 percent is in prospect for this year. With food prices relatively stable and disposable personal income up sharply, the percent of disposable personal income spent on food in 1976 was estimated to be less than the 17.1 percent in 1975. A further decline in the percent of disposable personal income spent on food cun be expected this year.

\section{OUTLOOK FOR MAJOR EIGHTH DISTRICT FARM PRODUCTS}

\section{Fecd Grains}

Feed grain supplies for the marketing year 1976-77 total about 231 million short tons or 4 percent more than a year ago. ${ }^{2}$ The harvest last fall was estimated at 212 million tons, 3 percent above the previous record in 1971 and 4 percent above the 1975 level. Carry. over stocks last fall totaled only 19 million tons, little different from the low carryover of a year earlier.

\footnotetext{
2Begins October 1 for corn and sorghum, which account for 81 and 10 percent of total feed grain production, respectively, and Jume 1 for oats and barley, which account for 5 and 4 percent, respectively.
} 


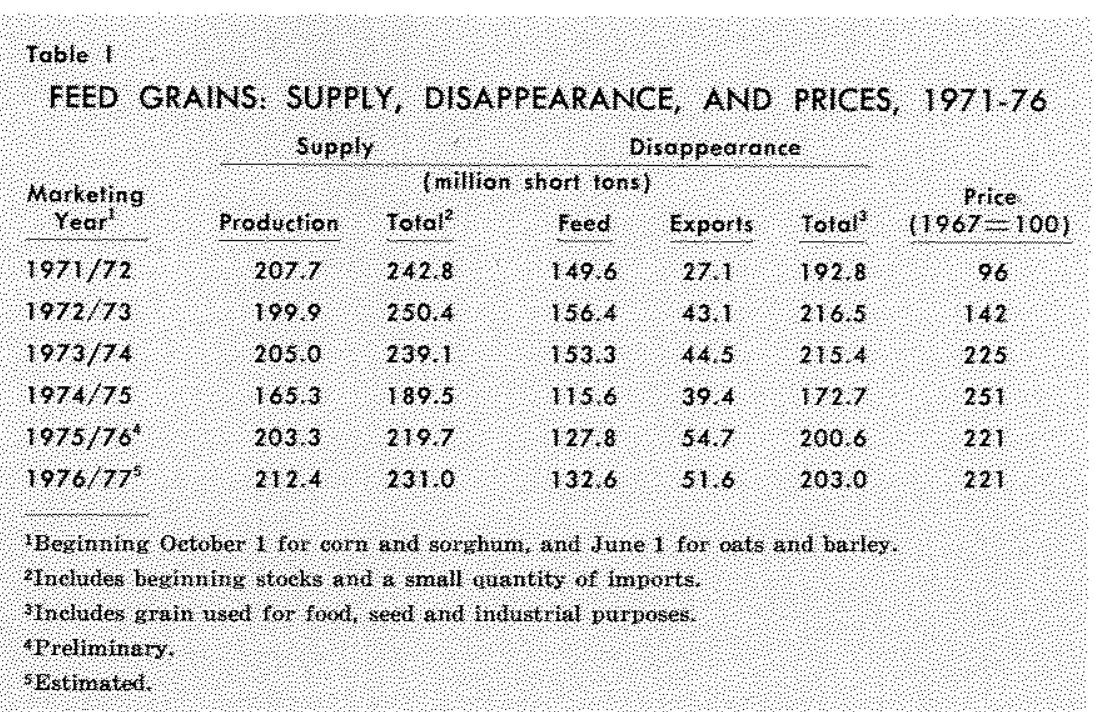

With the quantity of feed grain basically fixed for almost a year once the harvest is completed, changes in demand primarily determine prices until the new crop becomes a factor. The changes in demand for feed are primarily determined by the expected profits from feeding and changes in export demand. Given prospective demand conditions, near term profit margins from feeding appear to be relatively low. The number of livestock and poultry on feed is greater than a year ago, but with the recent unfavorable returns from feeding, the number on feed is expected to decline from current levels. Also, the larger than normal quantity of wheat fed to livestock will tend to reduce the demand for feed grain. Nevertheless, the quantity of feed grain consumed in the year is expected to rise to 133 million tons, up somewhat from the relatively low levels of the last two years, but well below the 153 million ton average for the three years $1971 / 72-1973 / 74$.

Despite the increased crop production abroad, feed grain exports are expected to approach the record level of last year when more than one-fourth of the U.S. crop was exported. Production in the U.S.S.R. recovered sharply from the drought-striken 1975 harvest, and their imports will be less than last year, but this decrease will be offset by increases elsewhere. The drought in Western Europe will probably result in some increased exports to these nations. Both the expansion of hog and poultry numbers throughout the European Community and Japan and the continuation of the world economic recovery tend to enhance demand for U.S. feed grain.

Feed grain prices in $1976 / 77$ are expected to average about the same as in 1975/76, down about 12 per- cent from the record high of $1974 / 75$, but still relatively high compared with other recent years.

\section{Wheat}

The 1976/77 wheat crop, estimated at 2,147 million bushels, is slightly above the record crop of a year earlier. Since beginning stocks totaled about 664 million bushels, approximately 2.8 billion bushels will be available for the year. This year domestic consumption of wheat is expected to rise to 795 million bushels from 729 million bushels last year, and exports are expected to decline to about 1,050 million bushels from about 1,175 million in $1975 / 76$. Consumption plus exports will thus total about $1,845 \mathrm{mil}-$ lion bushels, and carryover stocks at the end of June may rise to nearly one billion bushels, the largest wheat carryover since the mid-1960s.

The average price received by farmers for wheat in $1975 / 76$ was $\$ 3.52$ per bushel. With the large domestic supplies and reduced exports, however, wheat prices declined sharply in late 1976 and by last November were little above the price of feed grains.

At these relatively low prices greater wheat feeding is anticipated in the current marketing year than in most recent years. Wheat is usually considered to have about 10 percent more feeding value per bushel than corn, and thus, if com prices rise seasonally, as anticipated, there will be greater incentive for whent feeding, especially in feed-grain-deficit areas of the wheat beit, such as the Mountain and Pacific states.

Wheat prices are expected to rise seasonally during the winter months with a floor being determined largely by the price of feed grains. In the spring wheat prices are expected to become increasingly sensitive to crop conditions. Beyond next summer prices will depend heavily on Government farm pricing policies, particularly the price support loan rate and grain reserve policies.

\section{Rice}

The 1976 rice crop of 112 million hundredweight (cwt.) was 9 percent less than the year earlier record crop, but stocks of 37 million cwt. at the start of the harvest season resulted in relatively abundant supplies at prevailing market prices. The quantity of rice available for the year is at a record 149 million cwt. 
about 11 percent more than a year earlier. Carryover stocks estimated to total 45 million cwt. on August 1, 1977, will be up again.

Total domestic rice consumption and exports are expected to rise this year to about 104 million cwt. Domestic usage will be up about 3 million owt. and exports about 5 million cwt.

Farm prices for rice averaged $\$ 6.79$ per cwt. in the first three months of the season, somewhat above the $\$ 6.19$ per cwt. Loan rate, but well below the $\$ 8.25$ per cwt. Government target price. Thus, growers will be paid deficiency payments on their allotment production. The year 1977 is the final year of the twoyear Rice Production Act of 1975 which provides for a national allotment of 1.8 million acres, the same as in 1976, and a national average loan rate that is somewhat higher than $\$ 6.19$ per hundredweight. It also authorized a target price moderately above this year's $\$ 8.25$ per hundredweight with deficiency payments only on production from allotment acres. The January 1977 U.S. Department of Agriculture Survey of planting intentions indicates that farmers will plant 2.3 million acres of rice this year, 8.5 percent less than in 1976 and 18 percent less than in 1975.

\section{Oilseeds}

The outlook for oilseeds (largely soybeans and cottonseed) this year is characterized by sharply reduced supplies, rising demand, relatively high prices, and low carryover stocks next September 1.

The soybean harvest last fall of 1.26 billion bushels was only four-fifths as large as that of a year earlier. Carryover stocks totaled 244 million bushels providing a total supply of 1.5 billion bushels, about 200 million bushels less than last year.

Demand for soybeans is expected to remain relatively strong and soybean prices should average sharply higher than the $\$ 5$ per bushel received during $1975 / 76$. Total usage this year is projected at 1.4 billion bushels, 5 percent below last year, but about 100 million bushels in excess of last fall's harvest. Domestic crushings are expected to decline to 810 million bushels from 865 million a year earlier, and exports are expected to decline to 540 million from the 555 million record of $1975 / 76$.

Larger supplies of cottonseed will offset about 10 percent of the reduction in soybeans. The 1976 cottonseed crop, estimated at 4.0 million short tons, was about 28 percent greater than a year earlier.

\section{Cotton}

Relatively strong demand and small supplies highlight the $1976 / 77$ cotton prospects. The 1976 crop was estimated at 10.6 million bales, up 28 percent from the abnormally small 8.3 million bale 1975 crop, but well below that of recent years. Begiming stocks of 3.7 million bales last fall were 2 million less than a year earlier. But, the season's supply of 14.3 million bales is slightly above the small supply of 14.1 million bales a year ago.

A sharp increase in cotton exports is expected to more than offset a moderate decline in domestic usage. Total usage, projected at 10.9 million bales, is greater than last year's crop. Hence, reduced carryover stocks of cotton are in prospect for next fall. Domestic mill consumption is projected at 6.6 million bales, down from 7.25 million in $1975 / 76$. A strong increase in export demand, however, is underway and exports are expected to total 4.3 million bales, up from 3.3 million last year.

Cotton prices are well above the loan and Government target price levels. During the August-January months prices were up 15 cents or more per pound from a year earlier. Returns for the 1976 crop were estimated at $\$ 3.5$ billion, nearly equal to the 1973 record.

\section{Tobacco}

Tobacco supplies are up this year in both the United States and overseas. World production last year was down somewhat from the 11.7 billion pounds produced in 1975, largely as a result of a 3 percent reduction in the United States crop. The production of flue-cured tobacco in the United States was down 7 percent, but burley tobacco production rose 4 percent. Despite the smaller U.S. crop, the domestic supply of all tobacco is up about 2.4 percent from a year ago. The supply of flue-cured is up 4 percent and the supply of burley is up 2.5 percent.

While domestic use of tobacco has remained relatively stable in recent years, holding at about 1.3 billion pounds per year since 1965, unmanufactured tobacco exports have increased at a moderate rate. Exports of flue-cured tobacco declined from an average of 549 million pounds per year in the three years 1966-68 to 500 million pounds in 1976. Exports of burley tobacco, however, rose from 55 million pounds to 100 million pounds during the period. Total tobacco exports are expected to be about the same this year. 


\section{Meat Animals}

Operators of cattle and hog feeding enterprises are faced with an outlook for larger red meat supplies, rising demand, and somewhat lower average prices, especially in the first half of calendar 1977, than in the same period a year ago. The participants at the Outlook Conference thought that by midyear marketings of red meat would be declining, largely as a result of a decline in beef feeding. Now, however, it appears that red meat supplies will be relatively large throughout the year. As a result, prices of meat animals may not average much higher in the second half of the year than in the first half.

Analysts at the Outlook Conference predicted that cattle and calf slaughter this year would total about 44.7 million head, down 8 percent from 1976. Fed cattle slaughter was expected to decline slightly to about 24.7 million head, and nonfed steer and heifer slaughter to decline from the unusually high level of last year. However, in the October-December quarter placements of cattle and calves on feed were up 5 percent from a year ago, indicating a larger slaughter in the second half of the year than was originally expected. Per capita beef consumption in the United States totaled about 128 pounds in 1976, and with the larger than anticipated placements of cattle on feed, prospects are that beef production this year will approach the 1976 level. Consequently, per capita consumption may not be down much.

Despite the outlook for relatively large red meat supplies this winter and spring, the price of choice grade slaughter steers are expected to average somewhat higher for the entire year than last year. Such prices at Omaha have averaged less than the projected $\$ 41-\$ 43$ per hundredweight this winter, but a moderate increase in the spring months may occur as nonfed supplies decline. Hence, with the generally lower grain prices, cattle feeders should be able to recover feed costs and operate at a modest profit after the first quarter of the year, in contrast to sizable losses incurred by most feeders last year.

The cyclical pattern of cattle numbers points to generally rising prices for cattle in late 1977 and beyond. An inventory peak of 131.8 million head was reached in January 1975. The number was projected at 121.0 million at the beginning of 1977 , and a further decline of 2 to 3 percent is projected for this year.

In contrast to the outlook for declining cattle numbers, hog producers face an expansion phase of a hog cycle. Pork production last fall was up sharply from the year ago level. Slaughter in the first half of this year is forecast at 41 million head, up 25 percent from a year earlier, and slaughter in the second half of the year is forecast at 41.5 million head, up about 5 percent from the second half of last year.

At the indicated relatively high level of slaughter, especially in the early part of the year, hog prices are likely to average about $\$ 35$ per hundredweight in the first half of the year. This would mean reduced profits and some reduction in late 1977 farrowings, but the 1977 indicated slaughter of 80.82 million head points to pork production of over 13 billion pounds, or about 12 percent more than in 1976 . Hence, 1977 hog prices should average well below the $\$ 43$ per cwt. average for 1976 .

\section{Foultry}

Most poultry producers are currently operating at a loss, and the prospects for profitable operations are not good until the second half of the year after prices of red meat rise. First quarter output of broilers is expected to exceed the year earlier level by about 7 percent. By mid-year, however, production will probably drop back to about the year earlier level, and output in the second half of the year will depend on expected profits.

Broiler prices through the winter and spring months may show some small seasonal increase, but are likely to average about 3 cents per pound below the 42 cent average for the first half of 1976 .

\section{Eggs}

Egg producers experienced a profitable year in 1976 and the prospects for 1977 continue to be favorable. Egg production was up last year but fewer eggs were available to consumers because of reduced stocks at the beginning of the year and increased hatching usage.

Egg production is expected to increase 1 to 2 percent in the first half of this year from a year ago. Some further increase is foreseen in the second half of the year relative to year earlier levels if the currently favorable profit margins continue until mid-year.

The demand for eggs is expected to continue relatively strong in 1977, and in the first quarter prices may average 5 cents or more a dozen above year earlier levels. By the second quarter, however, prices may average only one or two cents above those of second quarter 1976, and in the second half of the year prices could decline below year earlier levels depending on the expansion of laying flocks during the year. 


\section{Dairy Products}

The dairy outlook is for larger milk supplies and lower average milk prices in 1977. Milk production in late 1976 was about 5.5 percent above that of the same period a year earlier and the higher than year earlier production level is expected to continue in early 1977. While production later in the year will depend largely on profit margins, milk production for the entire year is likely to exceed the 1976 level by one or two percent.

Milk prices in early 1977 will likely average well below those of a year earlier. Prices later in the year will depend on production movements, but the average price for all of 1977 may be below that of 1976 , the first annual decline in the farm price of milk since the $1950 \mathrm{~s}$.

\section{SUMMARY}

Realized net farm income in the nation in 1977 is expected to be well below the peak of $\$ 30$ billion in
1973 , but about equal the $\$ 24$ billion of 1975 and 1976. Prices received by farmers will probably average about the same as last year. Output of farm products will very likely continue upward and gross farm income is expected to rise proportionately. Higher production expenses are in prospect and are expected to offset the increase in gross income.

The outlook for farmers in the Eighth Federal Re serve District is not greatly different from the national outlook. Because of existing supplies, livestock feeders are faced with little or no profit from feeding for a few more months. By mid-year, livestock slaughter may decline somewhat, and profit margins may be improving. Crop supplies, with the exception of soybeans, are generally above year ago levels, but with rising demand for most crops average prices received by farmers at the beginning of this year were little different from a year earlier. Food grain prices were down sharply, and prices of feed grains were down slightly. Soybean prices were about 50 percent higher than a year ago, and tobacco and cotton prices were somewhat higher. 